\title{
Current Strategies for the Delivery of Therapeutic Proteins and Enzymes to Treat Brain Disorders
}

\author{
J.T. Duskey²，D. Belletti，F. Pederzoli，M.A. Vandelli，F. Forni, \\ B. Ruozi, G. Tosi ${ }^{1}$ \\ * Te.Far.T.I., University of Modena and Reggio Emilia, Modena, Italy \\ ${ }^{1}$ Corresponding author: Email address: gtosi@unimore.it (G. Tosi)
}

\section{Contents}

1. Introduction 2

2. Physical Delivery 5

3. Nonphysical Methods 19

3.1. Systemic Delivery 19

3.2. In Vitro Targeting 20

3.3. In Vivo Proteins, Fusion Proteins, and Modified Enzymes 22

3.4. Nanoparticle-Based Delivery 25

4. Conclusion $\quad 30$

References 31

\begin{abstract}
Brain diseases and injuries are growing to be one of the most deadly and costly medical conditions in the world. Unfortunately, current treatments are incapable of ameliorating the symptoms let alone curing the diseases. Many brain diseases have been linked to a loss of function in a protein or enzyme, increasing research for improving their delivery. This is no easy task due to the delicate nature of proteins and enzymes in biological conditions, as well as the many barriers that exist in the body ranging from those in circulation to the more specific barriers to enter the brain. Several main techniques are being used (physical delivery, protein/enzyme conjugates, and nanoparticle delivery) to overcome these barriers and create new therapeutics. This review will cover recently published data and highlights the benefits and deficits of possible new protein or enzyme therapeutics for brain diseases.
\end{abstract}

${ }^{2}$ Fondazione Umberto Veronesi Fellow. 


$\begin{array}{lc}\text { Abbreviations } \\ \text { DMPC } & \text { 1,2-dimyristoyl-sn-glycero-3-phosphocholine } \\ \text { DOPE } & \text { 1,2-dioleoyl-sn-glycero-3-phosphoethanolamine } \\ \text { IDUA } & \alpha \text {-L-iuronidase } \\ \alpha \text {-syn } & \alpha \text {-synuclein } \\ \text { Ang-2 } & \text { angiopep peptide-2 } \\ \text { ApoB } & \text { apolipoprotein B } \\ \text { bFGF } & \text { basic fibroblast growth factor } \\ \text { BBB } & \text { blood-brain barrier } \\ \text { BMM } & \text { bone marrow-derived macrophages } \\ \text { CNS } & \text { central nervous system } \\ \text { CSF } & \text { cerebral spinal fluid } \\ \text { CTB } & \text { cholera toxin B } \\ \text { ctCTLA-4 } & \quad \text { cytotoxic T-lymphocyte antigen } 4 \\ \text { EYPC } & \text { egg-yolk phosphatidylcholine } \\ \text { GDNF } & \text { glial cell-derived neurotophic factor } \\ \text { GSH-PEG } & \text { glutathione targeted PEG } \\ \text { GAGs } & \text { glycosaminoglycans } \\ \text { GFP } & \text { green fluorescent protein } \\ \text { icam1 } & \text { intercellular adhesion molecule 1 } \\ \text { LINCL } & \text { late infantile neuronal ceroid lipofuscinosis } \\ \text { MMP9 } & \text { matrix metalloproteinase-9 } \\ \text { MPS } & \text { mucopolysaccharidosis } \\ \text { MSA } & \text { multiple system atrophy } \\ \text { MBP } & \text { myelin basic protein } \\ \text { NEP } & \text { neprilysin } \\ \text { PPT1 } & \text { palmitoylprotein thioesterase-1 } \\ \text { PBCA } & \text { polybutylcyanoacrylate } \\ \text { PEG } & \text { poly ethylene glycol } \\ \text { PLGA } & \text { poly(lactic-co-glycolic acid) } \\ \text { rhSGSH } & \text { recombinant human sulfamidase } \\ \text { scFV's } & \text { single-chain fragment variables } \\ \text { TPP1 } & \text { tripeptidyl peptidase } \\ & \end{array}$

\section{INTRODUCTION}

Maladies of the brain lead to some of the most problematic diseases, in terms of symptoms and treatments. Any problem in the brain, disease, or injury related, can lead to communication problems, social 
disorders, organ failure, and death. In 2007, the World Health Organization claimed that $\sim 1$ billion people are affected with neurological disorders (WHO, 2001). By 2020, 10,000 people annually will be affected by traumatic brain injuries, with another 42 million affected by mild brain injuries, projected to become one of the leading causes of death world wide (Gardner \& Yaffe, 2015; Hyder, Wunderlich, Puvanachandra, Gururaj, \& Kobusingye, 2007; Ling, Hardy, \& Zetterberg, 2015). There is also an increasing rate of well-known diseases such as Alzheimer's (set to increase from 5.4 to between 11 and 16 million cases per year), Parkinson's (50,000 new cases diagnosed each year), autism, epilepsy (50 million per year), and psychiatric illness (suffered by one in four) (MIT, 2014; WHO, $2001)$. In the United States, an expected $\sim 18 \%$ of the population will be affected in their lifetime by a mental illness, impartial to age, sex, race, or economic well-being (Fig. 1) (NIMH, 2015).

With such high numbers, social and economic burdens of these diseases are also heavy. In Europe, it was estimated that $35 \%$ of the money

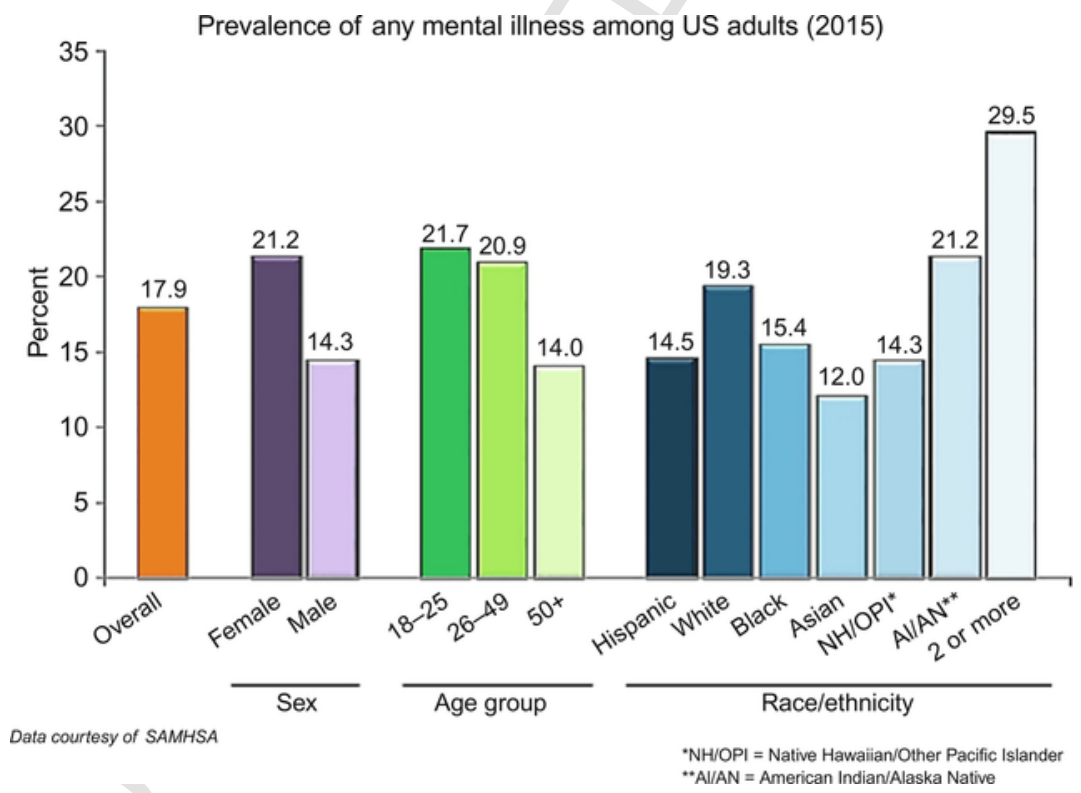

Fig. 1. Occurrence rate of mental illness in the United States (2015). Percent of population divided by common groups including sex, age, and ethnicity for the occurrence of a mental illness. Modified from NIH website (NIMH. Any mental illness (AMI) among U.S. adults. (2015). U.S. Department of Health and Human Services National Institute of Mental Health. Retrieved from https://www.nimh.nih.gov/health/statistics/prevalence/ any-mental-illness-ami-among-us-adults.shtml). 
used for treatments and diseases was due to neurological disorders. This is not only due to rising drug costs and treatments ( $€ 798$ billion as of 2010) but also due to the loss of time and productivity. The suffering and burden created by these disorders makes it critical to find new methods and improved treatments (MIT, 2014; Muro, 2010).

Discovering, designing, and testing new disease therapeutics is an incredibly difficult task. Millions of years of evolution improved the body's natural ability to defend and purify itself of foreign substances, rendering many therapeutics ineffective (Krol, 2012). Physical barriers-like the skin, filtration system of organs (i.e., liver, kidneys, and spleen), protein and enzyme activities which sequester and degrade foreign objects, and the immune system ensure protection from any foreign substances (Blanco, Shen, \& Ferrari, 2015; Finkelstein \& Weissmann, 1978; Mitragotri, 2005; Nehoff, Parayath, Domanovitch, Taurin, \& Greish, 2014). Therapeutics to treat brain diseases is also subject to extra barriers specifically designed to defend the control center of our bodies. The blood-brain barrier (BBB) controls passage of molecules into and out of the brain through a tightly interconnected cell network (tight junctions), receptor-specific access, and a series of efflux transporters (Chen \& Liu, 2012; Gabathuler, 2010; Mikitsh \& Chacko, 2014; Misra, Ganesh, Shahiwala, \& Shah, 2003; Upadhyay, 2014; Wohlfart, Gelperina, \& Kreuter, 2012; Wong, Wu, \& Bendayan, 2012). Furthermore, once into the brain parenchyma, the therapeutic must localize into the appropriate region of the brain, enter the correct cell type, and remain active in high enough concentrations for therapeutic effects. Many drug molecules and therapeutics do not naturally pass the $\mathrm{BBB}$ or cannot permeate into the brain parenchyma under healthy conditions, but only in some brain diseases which break down these barriers (Bramini et al., 2014; Nau, Sorgel, \& Eiffert, 2010; Tosi et al., 2016). Therefore, brain targeted therapeutics should be designed to enter and diffuse without damage (Krol et al., 2012). Very thorough and extensive literature describing the $\mathrm{BBB}$, the inability for many therapeutics to permeate the subcompartments of the brain, and the numerous other barriers of brain delivery exist and will not be discussed here (Alyautdin, Khalin, Nafeeza, Haron, \& Kuznetsov, 2014; Bhaskar et al., 2010; Garg, Bhandari, Rath, \& Goyal, 2015; Lu et al., 2014; Mitragotri, Burke, \& Langer, 2014; Patel, Zhou, Piepmeier, \& Saltzman, 2012; Singh \& Kapil, 2011; Wohlfart et al., 2012). 
Some small molecules have shown some therapeutic effectiveness but many brain diseases are caused by a protein or enzyme deficiency ( $\mathrm{Yi}$, Manickam, Brynskikh, \& Kabanov, 2014). Therefore, research of protein and enzyme therapeutics to correct the deficiency has increased. While replacing the defective protein/enzyme is a logical and natural option, numerous variables can lead to unsuccessful treatment making it a challenging task (Peluffo et al., 2015). Proteins and enzymes are more susceptible to systemic and brain barriers (protein binding, first pass clearance, immune response, attraversing the BBB, and off-target effects). Not only must they be delivered in high quantities, they must also remain intact, and for enzymes, the 3D orientation, and folding of the enzyme must be conserved (Calias, Banks, Begley, Scarpa, \& Dickson, 2014; Miners, Barua, Kehoe, Gill, \& Love, 2011; Pardridge, 2015; Yi \& Kabanov, 2013).

There are currently several main categories in which delivering proteins or enzymes to the brain are being persued. These include physical methods, systemic delivery, protein or enzyme conjugates, and nanoparticle-based delivery. This review will focus on describing the most recent avenues to treat brain diseases with therapeutic proteins or enzymes, and to highlight the benefits as well as the shortcomings of each.

\section{PHYSICAL DELIVERY}

Therapeutics and treatments for many diseases have rapidly progressed over the last century, while common methods for treating brain diseases have unfortunately remained somewhat barbaric. Instead of elegantly overcoming the numerous barriers such as the BBB, efflux pumps, tight junctions, and highly selective receptors present to block therapeutic delivery to the brain, many current treatments still rely on a direct injection to circumvent these obstacles (Gabathuler, 2010). Unfortunately, many drugs do not diffuse freely through the brain cavity requiring separate injections to reach all affected sites, making the difficulty, aggressiveness, and possibility for permanent damage of direct injection a serious concern (Glascock et al., 2011; Nau et al., 2010; Tosi et al., 2016; Wolak \& Thorne, 2013); However, this method, while crude, holds many advantages in the treatment of brain and central nervous system (CNS) disorders. Direct injection can specifically target the brain compartment and cells of interest removing the loss of first pass clearance and off-tar- 
get toxicity. Moreover, the stability and pharmacokinetic half-life of the protein or enzyme are less critical because they arrive directly at the site of action (Gabathuler, 2010; Marshall et al., 2015).

Vast numbers of articles are still being published to characterize direct injections into the different compartments of the CNS, and the effects and limitations of dosing various types of therapeutics in the brain (Marshall et al., 2015; Vuillemenot et al., 2011; Vuillemenot et al., 2015). Recently, Beard et al. tried to deconvolute the different effects of the recombinant human sulfamidase enzyme (rhSGSH) in the brain after administration into cerebral spinal fluid (CSF) compartments: intrathecal lumbar, cisternal, and ventricular (Beard et al., 2015). Understanding brain distribution is critical for improving currently tested therapeutics against diseases such as various lysosomal disorders, diabetes, blocking drug efflux (Cannon, Peart, Hawkins, Campos, \& Miller, 2012), and correcting damage to the CNS (a more comprehensive list can be found in Table 1).

While these treatments are still some of the most effective and highly sought after options, they are subject to many deficits. A major limiting factor is the invasiveness of inserting an object into the brain. Tearing a hole in the BBB increases chance of infection in the brain as well as increasing the chance of causing irreparable damage (Meng et al., 2014). This is often compounded by the need for improved circulation of the injected therapeutic throughout the brain compartments for effective treatment (Beard et al., 2015; Dickson et al., 2007; Marshall et al., 2015). This requires higher volumes/doses, and/or multiple injections, possibly into multiple locations. One option to extend effects and achieve higher volume doses in the brain is administration by infusion. The benefits of perfusion include controlled dosing speed and time, localization within the brain by bypassing the blood and filtration organs, ability to control the contents of the solute (including potential proteins or enzymes that could interfere), and the ability to analyze efflux rates by changing solutions (Cannon et al., 2012; Fujikawa et al., 2010; Katz et al., 2014; Smith \& Allen, 2003). In general, both direct injections and infusions are not viewed favorably by the public and are used due to a lack of other options. This becomes even more important when the age of onset of many brain disorders is taken into account. Many diseases, such as Alzheimer's, Parkinson's, and brain cancer are more predominant in older patients. Other diseases, such as late infantile neuronal ceroid lipo- 
TABLE 1 Physical Delivery to the Brain

\begin{tabular}{|c|c|c|c|c|c|c|c|}
\hline Year & Therapeutic & Malady $^{\mathrm{a}}$ & Therapeutic & Methods Tested $^{b}$ & Model & Conclusion & Citation \\
\hline 2007 & Enzyme & $\begin{array}{l}\text { Hurler } \\
\text { syndrome }\end{array}$ & $\begin{array}{l}\text { Recombinant human } \\
\text { iduronidase (rhIDU) }\end{array}$ & IT & Canine & $\begin{array}{l}\text { IT rhIDU } \\
\text { diffused } \\
\text { widely } \\
\text { throughout the } \\
\text { CNS. } \\
\text { Functional } \\
\text { with a } \\
\text { clinically } \\
\text { applicable } \\
\text { injection } \\
\text { frequency and } \\
\text { dose }\end{array}$ & Dickson et al. (2007) \\
\hline
\end{tabular}


TABLE 1 (Continued)

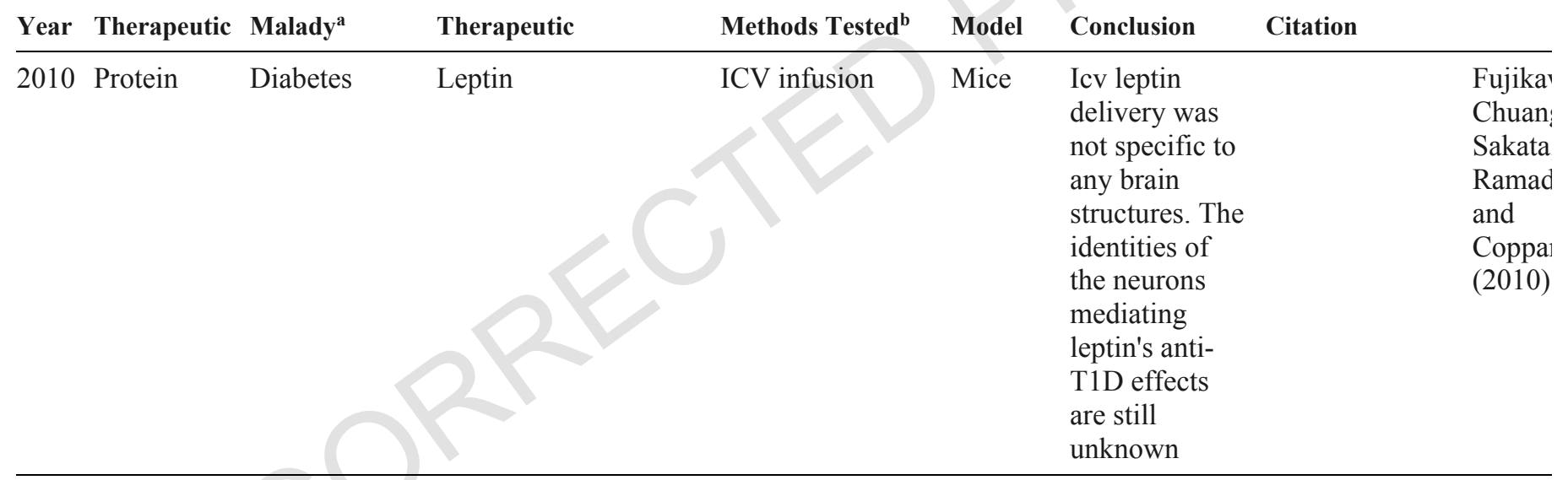


TABLE 1 (Continued)

\begin{tabular}{|c|c|c|c|c|c|c|c|}
\hline Year & Therapeutic & Malady $^{a}$ & Therapeutic & Methods Tested $^{\mathrm{b}}$ & Model & Conclusion & Citation \\
\hline 2011 & Enzyme & $\begin{array}{l}\text { Late infantile } \\
\text { neuronal } \\
\text { ceroid } \\
\text { lipofuscinosis } \\
\text { (LINCL) }\end{array}$ & $\begin{array}{l}\text { Tripeptidyl } \\
\text { peptidase-1 (TPP1) }\end{array}$ & $\begin{array}{l}\text { Four IT } \\
\text { administrations } \\
\text { formulated in } \\
\text { artificial } \\
\text { cerebrospinalfluid } \\
(\mathrm{aCSF})\end{array}$ & Canine & $\begin{array}{l}\text { Spike in TPP1 } \\
\text { concentration } \\
\text { in the CSF and } \\
\text { circulation. } \\
\text { However there } \\
\text { was a higher } \\
\text { immune } \\
\text { response in } \\
\text { afflicted mice. } \\
\text { Improvements } \\
\text { in brain } \\
\text { morphology } \\
\text { and cognitive } \\
\text { function were } \\
\text { not detected }\end{array}$ & Vuillemenot et al. (2011) \\
\hline
\end{tabular}


TABLE 1 (Continued)

\begin{tabular}{|c|c|c|c|c|c|c|c|}
\hline Year & Therapeutic & Malady $^{a}$ & Therapeutic & Methods Tested $^{b}$ & Model & Conclusion & Citation \\
\hline 2012 & Enzyme & $\begin{array}{l}\text { MPS II } \\
\text { (Hunters } \\
\text { syndrome) }\end{array}$ & $\begin{array}{l}\text { Iduronate-2-sulfatase } \\
\text { (I2S) }\end{array}$ & ICV and ITL & $\begin{array}{l}\text { Mice, } \\
\text { canine, } \\
\text { and } \\
\text { primates }\end{array}$ & $\begin{array}{l}\text { Both ICV and } \\
\text { ITL led to } \\
\text { extensive } \\
\text { distribution of } \\
\text { the enzyme. } \\
\text { The data } \\
\text { suggest } \\
\text { enzyme } \\
\text { distribution } \\
\text { could depend } \\
\text { on unknown } \\
\text { active transfer } \\
\text { processes }\end{array}$ & Calias et al. (2012) \\
\hline
\end{tabular}


TABLE 1 (Continued)

\begin{tabular}{|c|c|c|c|c|c|c|}
\hline Year & Therapeutic & Malady $^{a}$ & Methods Tested $^{\mathbf{b}}$ & Model & Conclusion & Citation \\
\hline 2014 & Enzyme & $\begin{array}{l}\text { Lysosomal } \\
\text { storage } \\
\text { diseases }\end{array}$ & $\begin{array}{ll}\text { Recombinant human } & \text { IV, intraspinal } \\
\text { sulfamidase } & \text { CSF infusion } \\
\text { (rhSGSH) } & \end{array}$ & Canine & $\begin{array}{l}\text { Penetration } \\
\text { after IT } \\
\text { injection was } \\
\text { suboptimal } \\
\text { earlier and } \\
\text { longer } \\
\text { treatments } \\
\text { must be tested }\end{array}$ & Marshall et al. (2015) \\
\hline
\end{tabular}


TABLE 1 (Continued)

\begin{tabular}{|c|c|c|c|c|c|c|c|}
\hline Year & Therapeutic & Maladya & Therapeutic & Methods Tested $^{b}$ & Model & Conclusion & Citation \\
\hline 2014 & Enzyme & $\begin{array}{l}\text { Neuronal } \\
\text { ceroid } \\
\text { lipofuscinosis } \\
\text { (CLN2) }\end{array}$ & $\begin{array}{l}\text { Tripeptidyl } \\
\text { peptidase-1 (TPP1) }\end{array}$ & $\begin{array}{l}\text { ICV catheter, ITL } \\
\text { catheter }\end{array}$ & Canine & $\begin{array}{l}\text { Detectable } \\
\text { delay of } \\
\text { neurological } \\
\text { deficits and } \\
\text { disease } \\
\text { progression } \\
\text { was slowed. } \\
\text { Canines } \\
\text { exhibited } \\
\text { improved } \\
\text { performance } \\
\text { on a cognitive } \\
\text { function test, } \\
\text { reduced brain } \\
\text { atrophy, and } \\
\text { increased life } \\
\text { span }\end{array}$ & Katz et al. (2014) \\
\hline
\end{tabular}


TABLE 1 (Continued)

\begin{tabular}{|c|c|c|c|c|c|c|c|}
\hline Year & Therapeutic & Maladya & Therapeutic & Methods Tested $^{\mathrm{b}}$ & Model & Conclusion & Citation \\
\hline 2014 & $\begin{array}{l}\text { Enzyme } \\
\text { fusion } \\
\text { protein }\end{array}$ & MPS IIIB & $\begin{array}{l}\text { IGFII modified } \alpha-N- \\
\text { acetylglucosaminidase } \\
\text { (NAGLU) }\end{array}$ & ICV & Mice & $\begin{array}{l}\text { Administration } \\
\text { led to an } \\
\text { almost } \\
\text { complete } \\
\text { reduction of } \\
\text { heparin sulfate } \\
\text { and a complete } \\
\text { reversal of } \\
\text { pathology } \\
\text { within } 2 \\
\text { weeks. } \\
\text { However large } \\
\text { amounts of } \\
\text { enzyme were } \\
\text { found in the } \\
\text { liver even after } \\
\text { ICV dosing }\end{array}$ & Kan et al. (2014) \\
\hline
\end{tabular}


TABLE 1 (Continued)

\begin{tabular}{|c|c|c|c|c|c|c|c|}
\hline Year & Therapeutic & Malady $^{\mathbf{a}}$ & Therapeutic & Methods Tested $^{\text {b }}$ & Model & Conclusion & Citation \\
\hline 2015 & Enzyme & $\begin{array}{l}\text { Neuronal } \\
\text { ceroid } \\
\text { lipofuscinosis } \\
\text { (CLN2) }\end{array}$ & $\begin{array}{l}\text { Recombinant human } \\
\text { tripeptidyl peptidase } \\
-1 \text { (rh-TPP } 1)\end{array}$ & ICV catheter & Canine & $\begin{array}{l}\text { rhTPP1 was } \\
\text { detected in all } \\
\text { areas of the } \\
\text { CNS leading } \\
\text { to decreased } \\
\text { lysosomal } \\
\text { storage } \\
\text { accumulation, } \\
\text { and improved } \\
\text { CNS cellular } \\
\text { phenotypes. } \\
\text { While an } \\
\text { increased } \\
\text { immune } \\
\text { response was } \\
\text { observed, } \\
\text { authors } \\
\text { claimed an } \\
\text { improved } \\
\text { safety profile }\end{array}$ & Vuillemenot et al. (2015) \\
\hline
\end{tabular}


TABLE 1 (Continued)

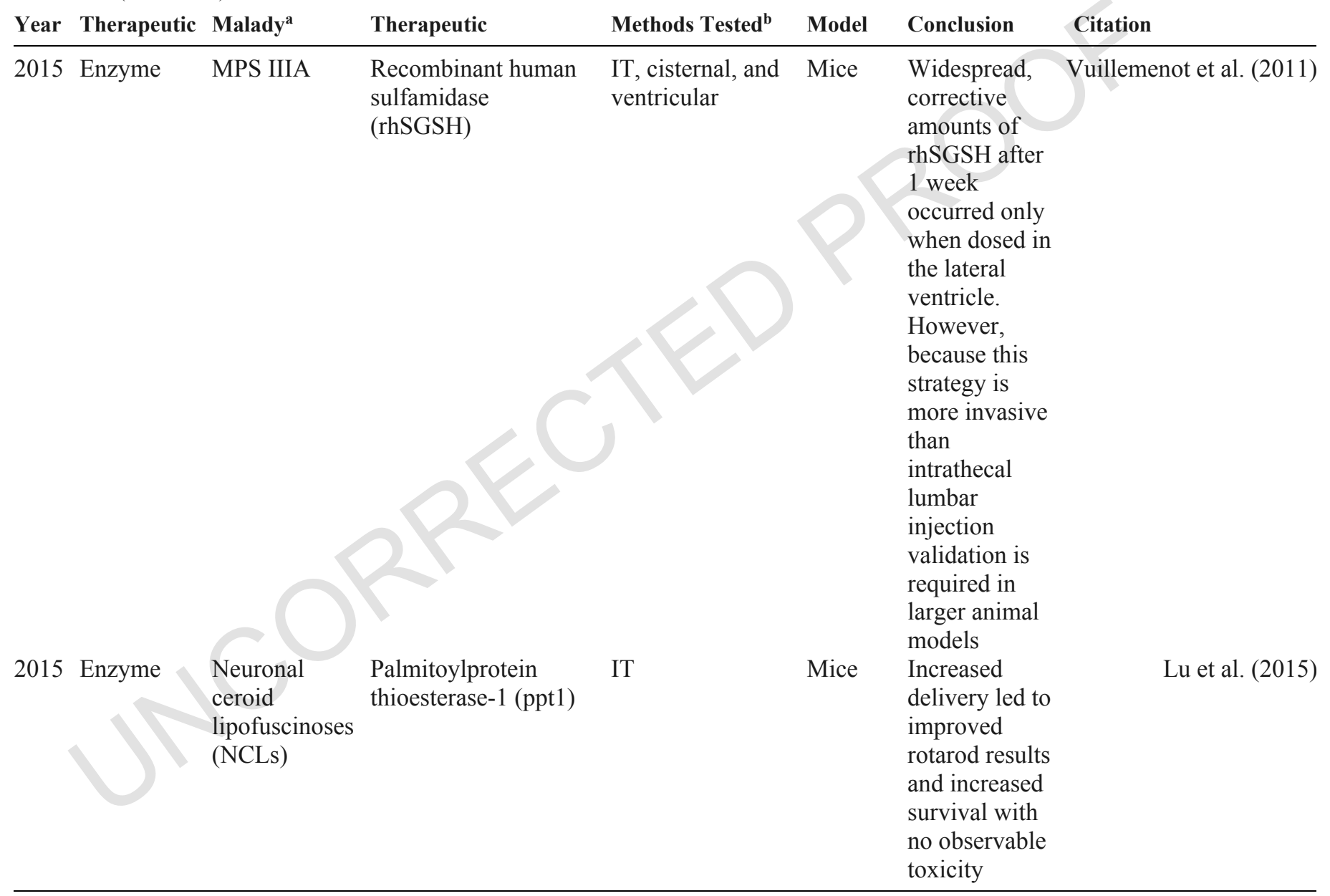




\begin{tabular}{|c|c|c|c|c|c|}
\hline 2015 Enzyme & $\begin{array}{l}\text { Spinal cord } \\
\text { damage }\end{array}$ & $\begin{array}{ll}\text { Sonic hedgehog }(\mathrm{Shh}) & \begin{array}{l}\text { Injection into the } \\
\text { contusion site }\end{array}\end{array}$ & Rats & $\begin{array}{l}\text { Dosing did not } \\
\text { negatively } \\
\text { impact the } \\
\text { progression of } \\
\text { a spinal cord } \\
\text { injury but only } \\
\text { led to a minor } \\
\text { decrease in } \\
\text { scaring } \\
\text { compared to } \\
\text { free enzyme. } \\
\text { Further } \\
\text { optimization is } \\
\text { required }\end{array}$ & $\begin{array}{l}\text { Rauck, } \\
\text { Novosi } \\
\text { Oudeg } \\
\text { and W: } \\
(2015)\end{array}$ \\
\hline
\end{tabular}




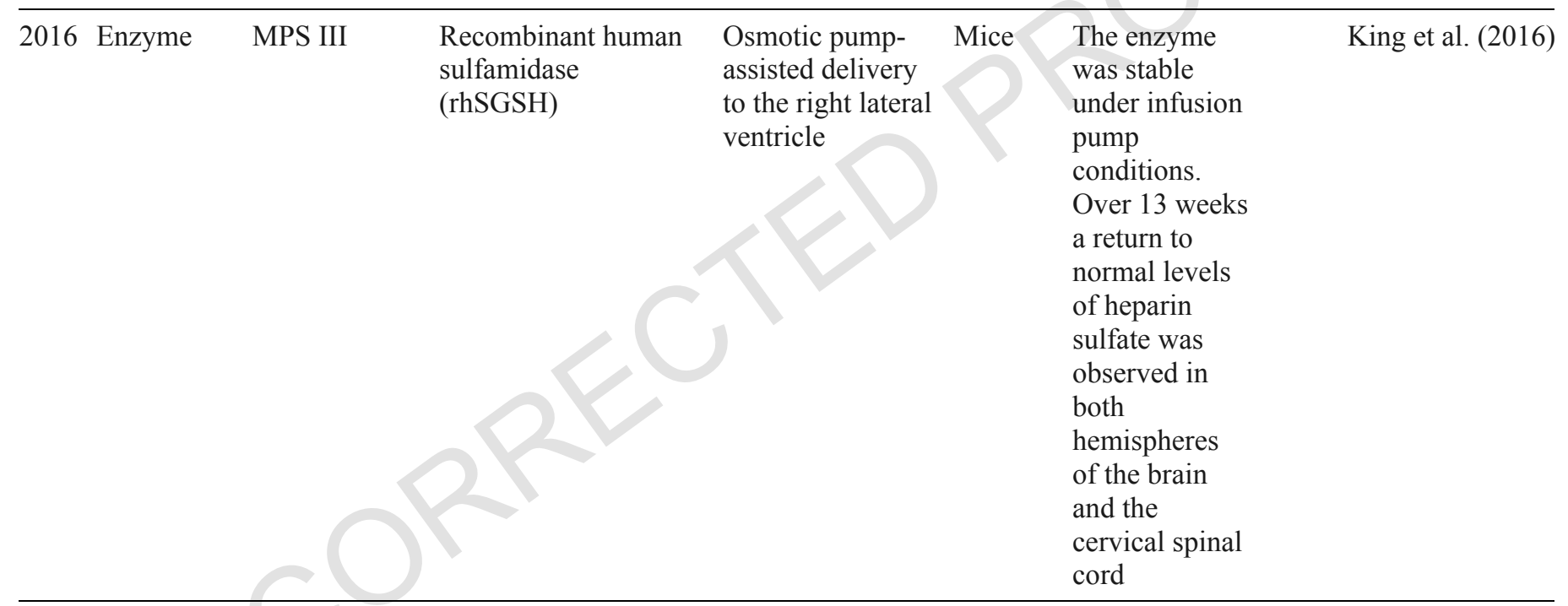

${ }^{a}$ Mucopolysaccharidosis (MPS).

'IT, Intrathecal; ICV, intracerebroventricular; ITL, intrathecal lumbar; IV, intravenous. 
fuscinosis (LINCL), Hurler syndrome, Krabbe disease, and many other lysosomal storage diseases are treated in young children, as the diseases often become fatal at a young age (Beard et al., 2015; Calias et al., 2012; Lu et al., 2015; Vuillemenot et al., 2011). The risk of permanent damage during treatment is greatly increased at young or older ages. Finally, the major drawback of these treatments currently is they often do not lead to a cure for the disease. Authors often express that while concentration in the desired region is enhanced, amelioration of the symptoms is not achieved. Furthermore, even if a therapeutic effect is observed, it only retards the progression of the symptoms as opposed to a permanent fix. This has led scientists to search for new, less invasive methods which can be used in addition to current treatments to provide safer and longer lasting therapeutic options.

Other physical delivery methods have also gained interest. Ultrasound can be used to create a therapeutic response. Ultrasound waves create oscillations in different tissues and lead to increased temperatures eliciting a biological response (Dasgupta et al., 2016; Hernot \& Klibanov, 2008; Mitragotri, 2005; Vykhodtseva, McDannold, \& Hynynen, 2008). More so, these waves can lead to cavitation of bubbles leading to a sheering force, which upon bursting the bubbles can create microjets that can stress or make tears in the tissue (Dasgupta et al., 2016; Park, Zhang, Vykhodtseva, \& McDannold, 2012). Ultrasound has now been used in numerous applications for the delivery of various types of therapeutic agents, mainly in organs other than the brain. In 2012, Wang et al. successfully delivered glial cell-derived neurotrophic factor (GDNF) conjugated-biotinylated lipid-coated microbubbles to the brain of rats (Wang et al., 2012). In this study, the protein delivery to the brain was increased $\sim 10$-fold compared to GDNF microbubbles without sonication. However, the authors also noticed a very large amount of BBB disruption. While, to the best of our knowledge, sonoporation has not been used for enzyme delivery to the brain, it has previously been used to increase enzyme activity targeted to the heart, seen in 2005 with the delivery of active luciferase into rat cardiac tissue (Bekeredjian, Chen, Grayburn, \& Shohet, 2005). This highlights its possible use for neurodegenerative diseases and brain delivery. This strategy is highly desirable due to the ability to directly modify microbubbles with different ligands and therapeutics, which when combined with more sensitive and tunable sonoporation techniques, leads to a very elegant and highly targeted technique (Ma et 
al., 2016; Xu et al., 2016). However, its inherent physical nature is a concern. The strong force upon destroying the microbubbles, leads to high amounts of disruption of the BBB hindering its protective function (Vykhodtseva et al., 2008). This force could also have negative effects on the activity or structure of the therapeutic protein and enzyme cargo leading to less efficient treatment options.

\section{NONPHYSICAL METHODS}

Physical methods have become more strategic and better understood; however, they still suffer from serious drawbacks for treating brain diseases. The danger, destructive nature, lack of brain distribution, and lack of symptom correction of physical methods make researching more elegant, functional, and mild methods of delivery critical (Beard et al., 2015; Marshall et al., 2015; Rauck et al., 2015). Nonphysical methods are highly sought after such as viral- or nanoparticle-based delivery. Not only do these suffer from all the barriers as physical methods such as the cell membrane, distribution in the brain, and short therapeutic duration, they must also be designed to overcome first pass clearance, instability in the blood, immune response, and off-target effects (Azad et al., 2015; Chen \& Liu, 2012; Lu et al., 2014; Upadhyay, 2014; Yi et al., 2014). To this end, the protein or enzyme must be protected to inhibit degradation, avoid protein binding in the blood (i.e., stealthed with poly(ethylene glycol) (PEG)), avoid clearance by the liver, have an extended pharmacokinetic half-life, and be targeted (peptide, antibody, aptamer, etc.) to cause brain accumulation and minimize off-target effects (Duskey \& Rice, 2014). While often in conflicting, all of these parameters must be optimized for any chance of therapeutic effect in clinical trials.

\subsection{Systemic Delivery}

Injection of proteins and enzymes into the blood stream is hindered by many factors. Both are naturally bound by blood proteins and removed by first pass clearance. Even if the molecule circulates in the blood, it is often degraded by proteases or is lost to off-target accumulation (Duskey $\&$ Rice, 2014). However, the severity of these diseases warrants any possible treatments to be examined. To overcome these barriers with systemic administration, one possibility is to perform multiple doses or dras- 
tically increase the dose of the therapeutic, effectively saturating systemic clearance but leading to enhanced accumulation in all tissues. One example was treating the lysosomal storage disease mucopolysaccharidosis type I (MPS1), an autosomal recessive brain disorder leading to death often before 10 years of age (Ou, Herzog, Koniar, Gunther, \& Whitley, 2014). A major barrier to treat this disease is that $\alpha$-L-iduronidase (IDUA) does not readily cross the $\mathrm{BBB}$. Therefore, researchers drastically increased the amount dosed intravenously in hopes that the small percent of such a large dose that can cross the BBB would be enough to see therapeutic effects. At a dose of $11.6 \mathrm{mg} / \mathrm{kg} /$ week in mice, levels of the enzyme increased to almost wild-type levels, reducing ganglioside levels by $63 \%$ and improving their water T-maze test results. While beneficial, the drastic increase in treatment costs to purify large quantities of enzyme and increased risk to the patients raise serious concerns about the feasibility of this kind of treatment in clinical trials. Increased accumulation in the other tissues, in this instance the heart, taxing the blood filtration organs, an increased possibility for an immune response, and adverse health effects cannot be tolerated. To this end, in 2015 a known treatment for children over six with Hunter's syndrome (Idursulfase beta: Hunterase ${ }^{\circledR}$ ) was administered consecutively over 52 weeks to determine the safety profile of repeat dosing (Sohn et al., 2015). Treatment led to a significant decrease in glycosaminoglycans (GAGs) of all patients, and none showed adverse reactions to the enzyme itself. However, $\sim 16 \%$ of patients showed adverse reaction to the repeated perfusion process and two-thirds of patients showed antibodies against Hunterase ${ }^{\circledR}$. Direct injection, large concentrations, and repeat doses are all short-term treatment options, but it is critical to find more stable and less aggressive alternatives. This requires a more sophisticated approach involving modified, conjugated, or encapsulated proteins and enzymes delivering therapeutic levels of enzymes to be specifically delivered to the brain while avoiding the barriers of clearance, binding, degradation, and off-target toxicity.

\subsection{In Vitro Targeting}

Scientists are incessantly searching for new ways to successfully treat brain diseases with less physically invasive methods. Therapeutic molecules are designed to optimize their stability, pharmacokinetic profile, and biodistribution in numerous animal models. Without each of these 
points being successful, it is impossible to create a viable therapeutic treatment. However, overcoming all of these barriers at once is an arduous task, and often can be separated by using relevant in vitro models. In vitro cell experiments are very useful, with various animal and human cell models for a wide array of diseases, either naturally occurring or created through gene knockout technology, including: Parkinson's, Alzeihmer's, lysosomal storage disorders, a wide variety of brain cancers, etc. Along with a large array of fluorophores, reporter molecules, and assay techniques available (Elisa, Western, protein pull down, fluorescent microscopy, etc.) in vitro experiments can give valuable data in a therapeutic molecules potential. Much more simplistic than an animal model, cell models are an effective way to more quickly analyze therapeutic factors. With an intact cell and nuclear membrane which express the proteins and receptors like normal cells, it is possible to quickly develop and screen compounds for their ability to enter the cell, either through nonspecific uptake or receptor-mediated entry, and test their activity. In recent years, in vitro assays have been invaluable for discovering targeting ligands or cell penetrating peptides which increase therapeutic entry across the BBB (Georgieva, Hoekstra, \& Zuhorn, 2014; Malakotikhah, Teixido, \& Giralt, 2008; Malakoutikhah, Guixer, Arranz-Gibert, Teixido, \& Giralt, 2014; Oller-Salvia, Sanchez-Navarro, Giralt, \& Teixido, 2016; Pardridge, 2015; Steichen, Caldorera-Moore, \& Peppas, 2013; Teixido $\&$ Giralt, 2012). More specifically, large screenings of different ligands (i.e., small molecules, peptides, proteins, etc.) have been analyzed for the ability to deliver enzyme cargo into various cell types (Acosta, Ayala, Dolan, \& Cramer, 2015; Eiamphungporn, Yainoy, \& Prachayasittikul, 2014; Gramlich et al., 2016). One such example used fluorescent-labeled cholera toxin B (CTB) to detect GM1-gangliosidosis and intercellular adhesion molecule 1 (icam1) to deliver enzymes into fibroblasts (Rappaport, Garnacho, \& Muro, 2014). While in vitro assays are useful for screening for activity and stability, alone they are severely flawed in designing enzyme and protein therapeutics that function in animal models or humans. Even with the cell barriers, in vitro assays lack the stresses found during circulation and crossing the BBB. Promising new models have emerged to more accurately mimic delivery to the BBB in vitro (Janigro, Leaman, \& Stanness, 1999; Wilhelm \& Krizbai, 2014). However, strong in vitro results rarely translate equally in vivo. This problem was addressed recently by Zuchero et al. who stated that litera- 
ture cited targets discovered in microarray screening rarely led to increased uptake in the brain (Zuchero et al., 2016). Using proteomic analysis, they identified protein targets on brain endothelial cells. Furthermore, they tested antibodies against these targets in mice to ensure increased brain accumulation. While useful at optimizing new protein and enzyme therapeutics, in vitro data alone are severely lacking and require simultaneously validation in vivo.

\subsection{In Vivo Proteins, Fusion Proteins, and Modified Enzymes}

The possibility for protein and enzyme therapeutics to overcome circulation, and uptake while remaining active is very narrow. Proteins and enzymes can be modified with stabilizing or targeting moieties to overcome these barriers. In recent years, peptide-modified enzymes have been extensively tested for enhancing brain delivery. For example, a peptide derived from the protein transduction domain of the human immunodeficiency virus protein (TAT), angiopep peptide (Ang-2), and variants of the apolipoprotein (ApoB, and ApoE-I and II) were used to deliver arylsulfatase A to a diseased mouse model (Bockenhoff et al., 2014). While all of these peptides enhance cellular uptake, ApoE-II-modified enzyme showed the largest accumulation in the brain, limiting clearance from the liver and spleen when compared with unmodified. However, the decrease in sulfidase storage was still far below that of wild-type mice. More interesting, Meng et al. showed these peptides also worked to deliver the enzyme tripeptidyl peptidase 1 (TPP1) when free in solution with the enzyme (not covalently bound) (Meng et al., 2014). The ability for these types of peptides to induce cell uptake has been known for a long time. In 1999 , groups were already attempting to deliver $\beta$-glucosidase to the brain with peptides such as TAT (Schwarze, Ho, Vocero-Akbani, \& Dowdy, 1999). While the number of peptides to enhance uptake has dramatically increased, the fact remains that very few have led to viable therapeutics over 2 decades and necessitates the design of more complex options.

Another option is to use a protein to activate the immune system against brain pathologies. Searching for a treatment for Alzheimer's and other dementia, one group dosed antibodies against the phosphorylated tau in diseased mouse models (Boutajangout, Ingadottir, Davies, \& Sigurdsson, 2011). Results showed that phfl antibody arrived in the dentate gyrus and motor cortex. This translated to a decrease in tau levels as 
well as improved traverse beam score results; however, no observable difference was seen in the other functional tests. In another mode, the cytoplasmic domain of cytotoxic T-lymphocyte antigen 4 (ctCTLA-4) was conjugated to a novel cell penetrating peptide for delivery to T-cells (Lim et al., 2015). This antigen downregulated the T-cells which are the cause of inflammation in multiple sclerosis, and when inhibited led to a significant improvement in uptake as well as clinical scores in a mouse model.

Fusion proteins are naturally occurring proteins, incorporating portions of various proteins into one molecule. Recent reviews summarize the concept, possibilities, and techniques for creating synthetic fusion proteins (Watts \& Dennis, 2013; Yu, Liu, Kim, \& Lee, 2015). Researchers can synthetically replicate this concept with the possibility to modify the physical, as well as functional characteristics of proteins, creating a potential candidate to target and treat brain diseases (Ou-Yang et al., 2015; Wang et al., 2012). One such result was to use a lentiviral vector to create a fusion protein of the LDL-R region of ApoB with single-chain fragment variables (scFVs) against $\alpha$-synuclein ( $\alpha$-syn) (Spencer et al., 2014a). Upon dosing the purified protein, not only did the fusion protein show a 20-30-fold increase of brain accumulation compared with the native antibody, uptake into neurons, and improved water maze results in mice, but the ability to produce the protein in mammalian cells greatly reduced the risk of immunogenic responses compared to those made in bacterial models.

Other advances combining fusion proteins with enzymes consisted of the Igg fusion protein containing an antibody targeted to the human insulin receptor (HIRMab) to deliver $\mathrm{N}$-sulfoglucosamine sulfamidase (SGSH) for the treatment of mucopolysaccharidosis type IIIA in monkeys (Boado, Lu, Hui, \& Pardridge, 2014). In vitro models showed an $83 \%$ decrease in sulfate levels, and when injected in vivo results showed an enhanced accumulation in the brain with therapeutic relevance (1\%). While $1 \%$ of dose was considered enough for corrective effects it is critical to optimize new formulations to increase brain accumulation. This will not only lead to better treatments but will also decrease doses and limit costs for future therapeutics.

Not only are fusion proteins a more sophisticated therapeutic molecule, but the mode of delivery also impacts their potential to treat brain disease. One method to enhance the fusion proteins therapeutic potential 
relied on plant cells to produce and bioencapsulate fusion proteins (Mäger, Roberts, Wood, \& El Andaloussi, 2014). Kohli et al. produced a fusion protein containing myelin basic protein (MBP) via a furin-cleavable linker to the CTB subunit in plant cells (Kohli et al., 2014). This production created the fusion protein within chloroplasts, protecting them during oral administration. Upon release the CTB portion promoted transcytosis across the intestinal epithelium and allowed rapid blood and organ delivery where MBP acted as the therapeutic reducing amyloid fibril formation found in Alzheimers' patients. When visualized with green fluorescent protein (GFP) only a small portion entered the brain, but the delivery of MBP led to a 70\% decrease in amyloid formation in mouse brain and retina. This method provides an intriguing solution to overcoming the barriers of brain delivery and is also unique due to its ability to be dosed orally.

Another interesting delivery method is genetically engineered modified enzymes in viral vectors. Although viral vectors usually fall into the category of nanoparticles and in general are not being discussed in this review, a few warrant mentioning here. Instead of using the viral vector to directly deliver therapeutics to the brain, labs engineered them to produce modified enzymes in vitro which were injected systemically. One such example against Alzheimer's disease used purified enzyme from cells infected with a virus coding the protease neprilysin (NEP) modified with the brain targeting moiety ApoB (Spencer et al., 2014b). Compared with the control vehicles, the targeted enzyme showed more than 10-fold increased localization with the neurons, as well as correction of symptoms to almost normal levels. Equally important, the mice showed very little immunogenic response to the dosed enzymes.

Removing the need and costs of protein purification, researchers took this idea one step further. By dosing the viral vectors directly to transfect a "depot organ" (usually the liver) for enzyme production and release into the blood circulation (Spencer et al., 2015). Two recent articles used this method to treat disease models of mucopolysaccharidoses type IIIA or multiple system atrophy (MSA) (Sorrentino et al., 2013; Spencer et al., 2015). In both cases, the accumulation in the brain was greatly enhanced and symptoms were almost completely corrected. This method had some of the most promising data seen to date for the ability to correct symptoms of a brain disorder and for its potential translatability to human clinical trials; however, great care must be taken as once the or- 
gan is transfected, the quantity of enzyme produced, as well as the immune response goes unmediated with potentially dangerous side effects.

Further research to reduce off-target uptake, enhance brain specificity, incorporate other therapeutics, and test them in higher animal models is necessary to find potential cures. All of these delivery methods have great promise in correcting these issues in mouse models and will dramatically impact future therapeutics against brain diseases.

\subsection{Nanoparticle-Based Delivery}

Nanoparticles offer a unique method to simultaneously combine multiple moieties into the same therapeutic for successfully treating brain diseases. The chemical and biological flexibility of nanoparticles is almost second to none compared with the other delivery methods. There are many types of nanoparticles based on lipids, polymers, dendrimers, inorganic nanoparticles, etc. (Young, Stenzelb, \& Yang, 2016) (Fig. 2). Reviews of general delivery with various nanoparticle types are abundant in the literature (Finkelstein \& Weissmann, 1978; Kreuter, 2014; Mahapatro \& Singh, 2011; Mignani et al., 2016; Posadas, Monteagudo,

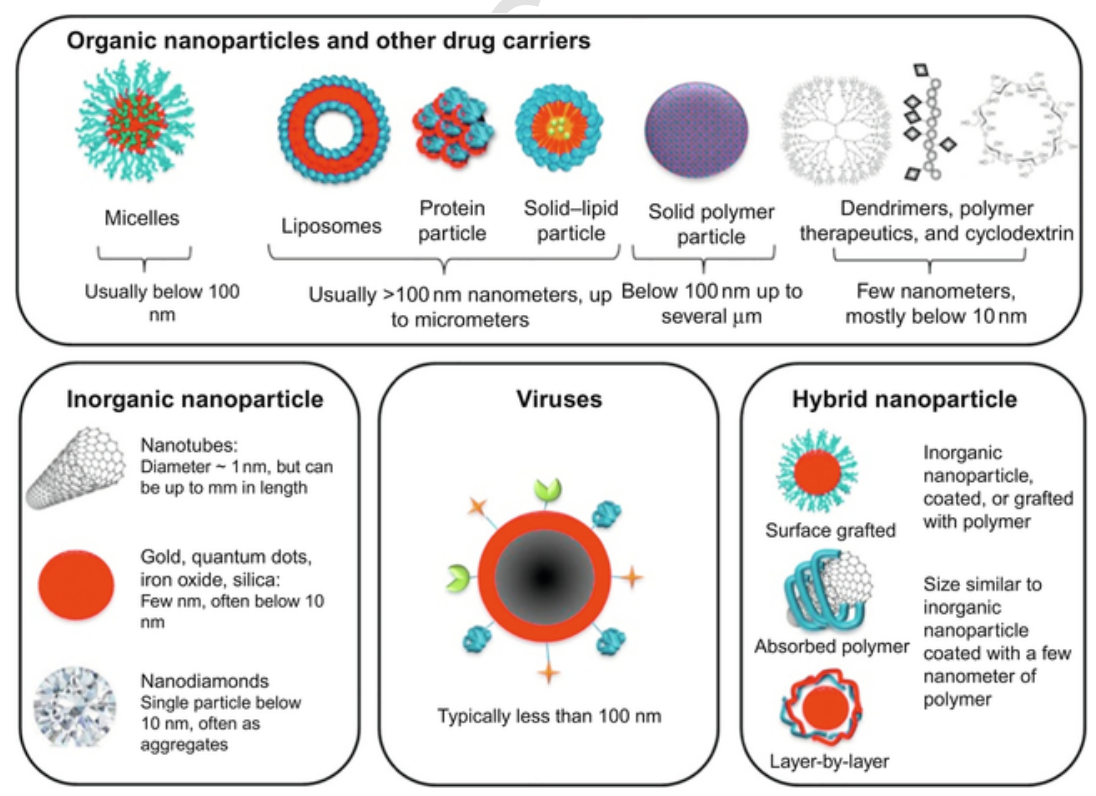

Fig. 2. Categories of nanoparticles. Reproduced from Young, S. W. S., Stenzelb, M., \& Yang, J.-L. (2016). Nanoparticle-siRNA: A potential cancer therapy? Critical Reviews in Oncology/Hematology, 98, 159-169 with Copyright permission. 
\& Cena, 2016; Tosi, Costantino, Ruozi, Forni, \& Vandelli, 2008). Depending on the core material, it is possible to finetune almost all physical characteristics of nanoparticles including: size, shape, charge, binding capacity, and hydrophobicity/hydrophilicity (internal and external). These factors correlate to the nanoparticle pharmacokinetic half life, biodistribution, stability, and binding capacity for the therapeutic protein or enzyme. Furthermore, many of these nanoparticles are suitable for further modification with targeting ligands or stealthing agents such as PEG. With so many possibilities, researchers can combine variables to optimize the particle for each individual protein, enzyme, and brain disease.

Recently protein only nanovectors have been tested for brain delivery (Estrada, Chu, \& Champion, 2014). In the literature protein, conjugates of this type accumulated in higher amounts than monomers alone (Serna et al., 2016). Serna et al. modified GFP with the peptide brain targeting ligands, ang-2 or seq, and a cationic tail (Serna et al., 2016). The ang-2 proteins remained as monomeric units under all conditions; however, the cationic tail aided in the formation of nanoparticles for the seq containing proteins. The theory and formation of these particles are significant because these could be translated directly to most if not all therapeutic proteins. However, upon evaluation in healthy mouse models, the targeted nanoparticle accumulation in the brain was indistinguishable to nontargeted. The difference between previous literature successes and lack of accumulation in the brain exemplifies the increased difficulty in delivering to the BBB over other organs. In a different approach, carbon nanospheres were covalently linked to the nuclear matrix-binding protein SMAR1 to treat a mouse model of human CNS demyelinating diseases, including MS and acute disseminated encephalomyelitis (Chemmannur, Bhagat, Mirlekar, Paknikar, \& Chattopadhyay, 2016). In this study, the modified carbon nanospheres showed no toxicity across all concentrations tested as well as uptake into proinflammatory th 17 cells. This induced a decrease in interleukins as well as an improved clinical score compared with the nanospheres alone over 19 days, but unfortunately long-term experiments were not conducted. While this method did not directly target the disease in the CNS, the nanospheres induced an effect in one part of the body that led to a therapeutic response in the brain in an autoimmune disease. This technology would be very interesting to 
combine with other targeted therapeutics to have additive/synergistic effects.

Poly(lactic-co-glycolic acid) (PLGA) is a biodegradable and biocompatible polymer approved by the US Food and Drug Administration for human use. This polymer forms nanoparticles which have been used to delivery various proteins to the brain (Fornaguera et al., 2015). In a series of articles, PLGA nanoparticles were directed to the brain either by coating them with polysorbate or targeted with a peptide ligand (g7) (Chaturvedi, Molino, Sreedhar, Khrestchatisky, \& Kaczmarek, 2014; Salvalaio et al., 2016). In both cases crossing the BBB was enhanced in comparison to nontargeted molecules, but only delivery was tested and further investigations into therapeutic relevance are required.

Liposomes were also used to delivery proteins to ameliorate the symptoms of Alzheimer's (Rotman et al., 2015). Glutathione-targeted PEGylated (GSH-PEG) liposomes formulated from either 1,2-dimyristoyl-sn-glycero-3-phosphocholine (DMPC) or egg-yolk phosphatidylcholine (EYPC) were loaded with amyloid beta binding llama single-domain antibody fragments (VHH-pa2H). In this way, the GSH-PEG helped particles cross the BBB, and upon destruction, release the antibody fragments targeting the amyloid plaques. Both types of liposomes, loaded with antibody fragments, greatly increased the pharmacokinetic half-life and brain uptake in an Alzheimer's mouse model compared to the antibody fragments alone; approximately 10-fold higher for GSH-PEG-EYPC (the better of the two formulations).

These results exemplify the positives and negatives of nanoparticle delivery to the brain. While any increase in therapeutic accumulation is a victory, and a 10 -fold increase is substantial, when the percentage of dose was measured even the best formulation only led to $\sim 0.023 \%$ of the injected dose in the brain. With such a low percent arriving in the brain and a lack of data testing the therapeutic effect, its relevance is minimal. Therefore, it is important to continue to improve targeting nanoparticles to deliver larger, therapeutically relevant amounts of protein into the brain.

Another route to enhance protein-loaded nanoparticle delivery to the brain is nasal delivery of drugs into the brain (Lin et al., 2016; Lochhead $\&$ Thorne, 2012). This method is less invasive than direct injection, but has many specific requirements for use as a viable delivery method (Appu, Arun, Krishnan, Moffett, \& Namboodiri, 2016). Like direct injec- 
tion, nasal delivery has the advantage of skipping first past clearance and can lead to distribution of the therapeutic to various CNS regions via access through the olfactory bulb and brainstem. This is exemplified by delivery of chloramphenicol acetyltransferase to various parts of the brain (Appu et al., 2016). When coupled with matrix metalloproteinase-9 (MMP-9), a molecule known to permeabilize the nasal epithelium, delivery was increased twofold to the midbrain and cortex, and $\sim 3$-fold to the brainstem. However, nasal delivery also has its faults. As reported, "the major disadvantage of nasal drug delivery is the limited absorption across the nasal epithelium and inadequate transport to the affected brain tissues. Although this can be overcome with permeation enhancers... the potential toxicity to the mucosal surface after repeated use of permeation enhancers has restricted their application" (Zhao et al., 2016). To this end, the same authors demonstrated the possibility for lipid nanoparticles loaded with basic fibroblast growth factor (bFGF) to treat a stroke model in rats (Zhao et al., 2016). Results showed that compared to free bFGF, accumulation in the brain was improved in the olfactory bulb, pallium, hippocampus, and striatum. This increased delivery also led to drastic decrease $(\sim 50 \%)$ in stroke infarct size and an extended life expectancy up to 21 days. Another group compared exosome delivery by intranasal vs intravenous injection (Haney et al., 2015). By fluorescent imaging, it was clear that intranasal delivery created a much higher rate of uptake than with intravenous delivery. Further analysis showed a decreased amount of activated microglial cells to levels near control mice. More information on the treatment of Parkinson's disease with exosomes was also covered recently in a review by the same group (Wu, Zheng, \& Zhang, 2016). These advances have shown the possibility to improve this method for functional use; however, are still limited in clinical use requiring new improved for advancing treatment of brain diseases (Garcia-Corvillo, 2016).

The physical characteristics of nanoparticles also make them suitable to encapsulate larger cargo like enzymes. There are many cases in which enzyme-loaded nanoparticles are tested for stability, cell uptake, and activity; however, few have been designed specifically for brain delivery (Lee et al., 2014; Ortac et al., 2014). One group compared different types of nanoparticles: liposomes, polybutylcyanoacrylate (PBCA), or PLGA, targeted with anti-NMDA ( $N$-methyl-D-aspartate) receptor 1 antibody (anti-NR1-SODPBCA NPs) (Yun et al., 2013). Although the amount 
antibody varied greatly between vehicle type, all particles showed brain accumulation leading to a $50 \%$ reduction in infarct size in an ischemic mouse model. In another example of liposomes, 1,2-dioleoyl-sn-glycero-3-phosphoethanolamine (DOPE) were modified with GNeo-NHS. In this way, both positive and negatively charged cargo could be encapsulated (Hamill, Wexselblatt, Tong, Esko, \& Tor, 2016). When loaded with a-L-iduronidase and delivered to fibroblast cells, a significant decrease in glycosaminoglycans was observed. Good uptake, loaded with functional enzyme, and the ability to encapsulate both positive and negative cargo permits the direct translation of these particles to other enzymes and diseases; however, effective targeting to better cross the BBB will be necessary to advance in vivo.

Another interesting targeted brain delivery method involved treating bone marrow-derived macrophages (BMM) with nanoformulated (PEI-PEG) catalase ex vivo (Zhao et al., 2011). The BMMs were then injected via tail vein or jugular vein and a dramatic increase in pharmacokinetic half life of the enzyme was observed. Furthermore, the BMMs naturally accumulated at sites of inflammation. This led to an increased accumulation in the brain over 7 days in a brain inflammation model. This was followed up by another paper in which they modified BMMs with GDNF leading to a significant decrease in inflammation and neurodegeneration in a Parkinson mouse model (Zhao et al., 2014). This method has very promising features because not only does it target the site of inflammation, and protect the enzyme, but also it could be personalized using BMMs from the patient themselves limiting the possibility for an immune response.

Nanoparticles offer the largest number of controllable variables of all therapeutic options ranging both in physical characteristics, and possible therapeutic options. Because of this, it is often very difficult to draw conclusions about the relevance of the data in comparison to the others. Each system offers different positive features, and currently none have stood out as having a clear advantage for clinical success. Future works will continue to require combining little victories from each piece of research to optimize and to find viable protein and enzyme-based treatments for brain diseases. 


\section{CONCLUSION}

Brain disease rates are increasing worldwide at an astounding rate. They will soon become one of the most deadly and expensive medical costs in the world. Unfortunately, there are currently very few successful treatments. Because many of these diseases can be traced to a missing or deficient protein or enzyme, finding new ways to protect and specifically deliver these molecules into the brain need to be discovered. To be effective, these new therapeutics must bypass the initial biological barriers including: administration, sequestration and degradation in the blood, first pass clearance, off-target accumulation, and the immune response. Adding to the difficulty, they must also cross the BBB, diffuse through the brain compartments and be able to enter the deficient cells to create a therapeutic effect.

Research has uncovered many avenues in which we can approach the treatment of brain diseases using therapeutic protein or enzyme replacement therapy. These range from physical methods, conjugates, or nanoparticle delivery. Each offers unique advantages over the other. Direct injection can deliver intact proteins and enzymes into the brain by bypassing almost all major physical barriers; however, it is extremely invasive, compounded often by the need for repeated treatments. Proteins and enzyme conjugates can be used to increase stability, targeting, crossing the $\mathrm{BBB}$, and cell penetration, but often fail to combine them all into one functional system. The versatility of nanoparticle-based delivery improves on direct conjugation by affording protection and further functionalization options to increase the pharmacokinetic half life, targeting, and delivery, but still falls short of creating a complete system in which all variables are combined. These disadvantages have drastically limited the number of clinical trials and successful therapeutics that have reached the market.

For future research, combining treatments and methods are necessary. For example, combining physical methods with nanoparticles, advancing bioconjugate technologies to enhance the delivery, stability, pharmacokinetics, delivery across the BBB, and diffusion through the brain compartments while simultaneously stabilizing the protein or enzyme are necessary. Only if all of these factors are combined into a single delivery vehi- 
cle will it be possible to create a clinically relevant protein or enzyme therapeutic for brain diseases.

\section{REFERENCES}

Acosta, W., Ayala, J., Dolan, M.C., Cramer, C.L., 2015. RTB lectin: A novel receptor-independent delivery system for lysosomal enzyme replacement therapies. Scientific Reports 5.

Alyautdin, R., Khalin, I., Nafeeza, M.I., Haron, M.H., Kuznetsov, D., 2014. Nanoscale drug delivery systems and the blood-brain barrier. International Journal of Nanomedicine 9, 795-811.

Appu, A.P., Arun, P., Krishnan, J.K.S., Moffett, J.R., Namboodiri, A.M.A., 2016. Rapid intranasal delivery of chloramphenicol acetyltransferase in the active form to different brain regions as a model for enzyme therapy in the CNS. Journal of Neuroscience Methods 259, 129-134.

Azad, T.D., et al., 2015. Therapeutic strategies to improve drug delivery across the blood-brain barrier. Neurosurgical Focus 38, E9.

Beard, H., et al., 2015. Determination of the role of injection site on the efficacy of intra-CSF enzyme replacement therapy in MPS IIIA mice. Molecular Genetics and Metabolism 115, 33-40.

Bekeredjian, R., Chen, S.Y., Grayburn, P.A., Shohet, R.V., 2005. Augmentation of cardiac protein delivery using ultrasound targeted microbubble destruction. Ultrasound in Medicine and Biology 31, 687-691.

Bhaskar, S., et al., 2010. Multifunctional nanocarriers for diagnostics, drug delivery and targeted treatment across blood-brain barrier: Perspectives on tracking and neuroimaging. Particle and Fibre Toxicology 7, 3.

Blanco, E., Shen, H., Ferrari, M., 2015. Principles of nanoparticle design for overcoming biological barriers to drug delivery. Nature Biotechnology 33, 941-951.

Boado, R.J., Lu, J.Z., Hui, E.K.W., Pardridge, W.M., 2014. Insulin receptor antibody-sulfamidase fusion protein penetrates the primate blood-brain barrier and reduces glycosoaminoglycans in sanfilippo type A cells. Molecular Pharmaceutics 11, 2928-2934.

Bockenhoff, A., et al., 2014. Comparison of five peptide vectors for improved brain delivery of the lysosomal enzyme arylsulfatase A. Journal of Neuroscience 34, 3122-3129.

Boutajangout, A., Ingadottir, J., Davies, P., Sigurdsson, E.M., 2011. Passive immunization targeting pathological phospho-tau protein in a mouse model reduces functional decline and clears tau aggregates from the brain. Journal of Neurochemistry 118, $658-667$.

Bramini, M., et al., 2014. Imaging approach to mechanistic study of nanoparticle interactions with the blood-brain barrier. ACS Nano 8, 4304-4312.

Calias, P., Banks, W.A., Begley, D., Scarpa, M., Dickson, P., 2014. Intrathecal delivery of protein therapeutics to the brain: A critical reassessment. Pharmacology \& Therapeutics $144,114-122$.

Calias, P., et al., 2012. CNS penetration of Intrathecal-lumbar idursulfase in the monkey, dog and mouse: Implications for neurological outcomes of lysosomal storage disorder. PLoS One 7. 
Cannon, R.E., Peart, J.C., Hawkins, B.T., Campos, C.R., Miller, D.S., 2012. Targeting blood-brain barrier sphingolipid signaling reduces basal P-glycoprotein activity and improves drug delivery to the brain. Proceedings of the National Academy of Sciences of the United States of America 109, 15930-15935.

Chaturvedi, M., Molino, Y., Sreedhar, B., Khrestchatisky, M., Kaczmarek, L., 2014. Tissue inhibitor of matrix metalloproteinases-1 loaded poly(lactic-co-glycolic acid) nanoparticles for delivery across the blood-brain barrier. International Journal of Nanomedicine 9, 14.

Chemmannur, S.V., Bhagat, P., Mirlekar, B., Paknikar, K.M., Chattopadhyay, S., 2016. Carbon nanospheres mediated delivery of nuclear matrix protein SMAR1 to direct experimental autoimmune encephalomyelitis in mice. International Journal of Nanomedicine 11, 2039-2051.

Chen, Y., Liu, L.H., 2012. Modern methods for delivery of drugs across the blood-brain barrier. Advanced Drug Delivery Reviews 64, 640-665.

Dasgupta, A., et al., 2016. Ultrasound-mediated drug delivery to the brain: Principles, progress and prospects. Drug Discovery Today: Technologies 20, 41-48.

Dickson, P., et al., 2007. Intrathecal enzyme replacement therapy: Successful treatment of brain disease via the cerebrospinal fluid. Molecular Genetics and Metabolism 91, $61-68$.

Duskey, J.T., Rice, K.G., 2014. Nanoparticle ligand presentation for targeting solid tumors. AAPS PharmSciTech 15, 1345-1354.

Eiamphungporn, W., Yainoy, S., Prachayasittikul, V., 2014. Angiopep-2-mediated delivery of human manganese superoxide dismutase in brain endothelial cells and its protective effect against oxidative stress. International Journal of Peptide Research and Therapeutics 21, 63-71.

Estrada, L.H., Chu, S., Champion, J.A., 2014. Protein nanoparticles for intracellular delivery of therapeutic enzymes. Journal of Pharmaceutical Sciences 103, 1863-1871.

Finkelstein, M., Weissmann, G., 1978. The introduction of enzymes into cells by means of liposomes. Journal of Lipid Research 19, 289-303.

Fornaguera, C., et al., 2015. PLGA nanoparticles prepared by nano-emulsion templating using low-energy methods as efficient nanocarriers for drug delivery across the blood-brain barrier. Journal of Controlled Release 211, 134-143.

Fujikawa, T., Chuang, J.C., Sakata, I., Ramadori, G., Coppari, R., 2010. Leptin therapy improves insulin-deficient type 1 diabetes by CNS-dependent mechanisms in mice. Proceedings of the National Academy of Sciences of the United States of America 107, 17391-17396.

Gabathuler, R., 2010. Approaches to transport therapeutic drugs across the blood-brain barrier to treat brain diseases. Neurobiology of Disease 37, 48-57.

Garcia-Corvillo, M.D., 2016. Polymeric nanoparticles for drug delivery to the central nervous system via nasal route. Ars Pharmaceutica 57, 27-35.

Gardner, R.C., Yaffe, K., 2015. Epidemiology of mild traumatic brain injury and neurodegenerative disease. Molecular and Cellular Neuroscience 66, 75-80.

Garg, T., Bhandari, S., Rath, G., Goyal, A.K., 2015. Current strategies for targeted delivery of bio-active drug molecules in the treatment of brain tumor. Journal of Drug Targeting $23,865-887$. 
Georgieva, J.V., Hoekstra, D., Zuhorn, I.S., 2014. Smuggling drugs into the brain: An overview of ligands targeting transcytosis for drug delivery across the blood-brain barrier. Pharmaceutics 6, 557-583.

Glascock, J.J., et al., 2011. Delivery of therapeutic agents through intracerebroventricular (ICV) and intravenous (IV) injection in mice. Jove-Journal of Visualized Experiments

Gramlich, P.A., et al., 2016. A peptide-linked recombinant glucocerebrosidase for targeted neuronal delivery: Design, production, and assessment. Journal of Biotechnology 221, $1-12$.

Hamill, K.M., Wexselblatt, E., Tong, W.Y., Esko, J.D., Tor, Y., 2016. Delivery of an active lysosomal enzyme using GNeosomes. Journal of Materials Chemistry B 4, 5794-5797.

Haney, M.J., et al., 2015. Exosomes as drug delivery vehicles for Parkinson's disease therapy. Journal of Controlled Release 207, 18-30.

Hernot, S., Klibanov, A.L., 2008. Microbubbles in ultrasound-triggered drug and gene delivery. Advanced Drug Delivery Reviews 60, 1153-1166.

Hyder, A.A., Wunderlich, C.A., Puvanachandra, P., Gururaj, G., Kobusingye, O.C., 2007. The impact of traumatic brain injuries: A global perspective. NeuroRehabilitation 22, 341-353.

Janigro, D., Leaman, S.M., Stanness, K.A., 1999. Dynamic in vitro modeling of the blood-brain barrier: A novel tool for studies of drug delivery to the brain. Pharmaceutical Science \& Technology Today 2, 7-12.

Kan, S., et al., 2014. Delivery of an enzyme-IGFII fusion protein to the mouse brain is therapeutic for mucopolysaccharidosis type IIIB. Proceedings of the National Academy of Sciences of the United States of America 111, 14870-14875.

Katz, M.L., et al., 2014. Enzyme replacement therapy attenuates disease progression in a canine model of late-infantile neuronal ceroid lipofuscinosis (CLN2 disease). Journal of Neuroscience Research 92, 1591-1598.

King, B., et al., 2016. Low-dose, continuous enzyme replacement therapy ameliorates brain pathology in the neurodegenerative lysosomal disorder mucopolysaccharidosis type IIIA. Journal of Neurochemistry 137, 409-422.

Kohli, N., et al., 2014. Oral delivery of bioencapsulated proteins across blood-brain and blood-retinal barriers. Molecular Therapy 22, 535-546.

Kreuter, J., 2014. Drug delivery to the central nervous system by polymeric nanoparticles: What do we know?. Advanced Drug Delivery Reviews 71, 2-14.

Krol, S., 2012. Challenges in drug delivery to the brain: Nature is against us. Journal of Controlled Release 164, 145-155.

Krol, S., et al., 2012. Therapeutic benefits from nanoparticles: The potential significance of nanoscience in diseases with compromise to the blood brain barrier. Chemical Reviews 113, 1877-1903.

Lee, H.J., et al., 2014. Enzyme delivery using the $30 \mathrm{Kc} 19$ protein and human serum albumin nanoparticles. Biomaterials 35, 1696-1704.

Lim, S., et al., 2015. dNP2 is a blood-brain barrier-permeable peptide enabling ctCTLA-4 protein delivery to ameliorate experimental autoimmune encephalomyelitis. Nature Communications 6, 8244.

Lin, T.T., et al., 2016. Nose-to-brain delivery of macromolecules mediated by cell-penetrating peptides. Acta Pharmaceutica Sinica B 6, 352-358. 
Ling, H., Hardy, J., Zetterberg, H., 2015. Neurological consequences of traumatic brain injuries in sports. Molecular and Cellular Neuroscience 66, 114-122.

Lochhead, J.J., Thorne, R.G., 2012. Intranasal delivery of biologics to the central nervous system. Advanced Drug Delivery Reviews 64, 614-628.

Lu, C.T., et al., 2014. Current approaches to enhance CNS delivery of drugs across the brain barriers. International Journal of Nanomedicine 9, 2241-2256.

Lu, J.Y., et al., 2015. Intrathecal enzyme replacement therapy improves motor function and survival in a preclinical mouse model of infantile neuronal ceroid lipofuscinosis. Molecular Genetics and Metabolism 116, 98-105.

Ma, J., et al., 2016. Biodegradable double-targeted PTX-mPEG-PLGA nanoparticles for ultrasound contrast enhanced imaging and antitumor therapy in vitro. OncoTarget 7, 80008-80018.

Mäger, I., Roberts, C., Wood, M., El Andaloussi, S., 2014. From gut to brain: Bioencapsulated therapeutic protein reduces amyloid load upon oral delivery. Molecular Therapy 22 (3), 485-486.

Mahapatro, A., Singh, D.K., 2011. Biodegradable nanoparticles are excellent vehicle for site directed in-vivo delivery of drugs and vaccines. Journal of Nanobiotechnology 9 , 55.

Malakotikhah, M., Teixido, M., Giralt, E., 2008. Toward an optimal blood-brain barrier shuttle by synthesis and evaluation of peptide libraries. Journal of Medicinal Chemistry $51,4881-4889$.

Malakoutikhah, M., Guixer, B., Arranz-Gibert, P., Teixido, M., Giralt, E., 2014. 'A la Carte' peptide shuttles: Tools to increase their passage across the blood-brain barrier. ChemMedChem 9, 1594-1601.

Marshall, N.R., et al., 2015. Delivery of therapeutic protein for prevention of neurodegenerative changes: Comparison of different CSF-delivery methods. Experimental Neurology 263, 79-90.

Meng, Y., et al., 2014. Effective intravenous therapy for neurodegenerative disease with a therapeutic enzyme and a peptide that mediates delivery to the brain. Molecular Therapy $22,547-553$.

Mignani, S., et al., 2016. Can dendrimer based nanoparticles fight neurodegenerative diseases? Current situation versus other established approaches. Progress in Polymer Science $64,23-51$.

Mikitsh, J.L., Chacko, A.-M., 2014. Pathways for small molecule delivery to the central nervous system across the blood-brain barrier. Perspectives in Medicinal Chemistry $6,11-24$.

Miners, J.S., Barua, N., Kehoe, P.G., Gill, S., Love, S.A., 2011. Beta-degrading enzymes: Potential for treatment of Alzheimer disease. Journal of Neuropathology and Experimental Neurology 70, 944-959.

Misra, A., Ganesh, S., Shahiwala, A., Shah, S.P., 2003. Drug delivery to the central nervous system: A review. Journal of Pharmacy and Pharmaceutical Sciences 6, 252-273.

MIT, 2014. Brain disorders by numbers. In: https://mcgovern.mit.edu/brain-disorders/ by-the-numbers.

Mitragotri, S., 2005. Innovation-Healing sound: The use of ultrasound in drug delivery and other therapeutic applications. Nature Reviews Drug Discovery 4, 255-260. 
Mitragotri, S., Burke, P.A., Langer, R., 2014. Overcoming the challenges in administering biopharmaceuticals: Formulation and delivery strategies. Nature Reviews Drug Discovery $13,655-672$.

Muro, S., 2010. New biotechnological and nanomedicine strategies for treatment of lysosomal storage disorders. Wiley Interdisciplinary Reviews. Nanomedicine and Nanobiotechnology 2, 189-204.

Nau, R., Sorgel, F., Eiffert, H., 2010. Penetration of drugs through the blood-cerebrospinal fluid/blood-brain barrier for treatment of central nervous system infections. Clinical Microbiology Reviews 23, 858.

Nehoff, H., Parayath, N.N., Domanovitch, L., Taurin, S., Greish, K., 2014. Nanomedicine for drug targeting: Strategies beyond the enhanced permeability and retention effect. International Journal of Nanomedicine 9, 2539-2555.

NIMH, 2015. Any mental illness (AMI) among U.S. adults. US Department of Health and Human Services National Institute of Mental Health, Retrieved from https://www. nimh.nih.gov/health/statistics/prevalence/any-mental-illness-ami-among-us-adults. shtml.

Oller-Salvia, B., Sanchez-Navarro, M., Giralt, E., Teixido, M., 2016. Blood-brain barrier shuttle peptides: An emerging paradigm for brain delivery. Chemical Society Reviews 45, 4690-4707.

Ortac, I., et al., 2014. Dual-porosity hollow nanoparticles for the immunoprotection and delivery of nonhuman enzymes. Nano Letters 14, 3023-3032.

Ou, L., Herzog, T., Koniar, B.L., Gunther, R., Whitley, C.B., 2014. High-dose enzyme replacement therapy in murine Hurler syndrome. Molecular Genetics and Metabolism $111,116-122$.

Ou-Yang, M.H., et al., 2015. The N-terminal region of myelin basic protein reduces fibrillar amyloid-beta deposition in Tg-5xFAD mice. Neurobiology of Aging 36, 801-811.

Pardridge, W.M., 2015. Targeted delivery of protein and gene medicines through the blood-brain barrier. Clinical Pharmacology \& Therapeutics 97, 347-361.

Park, E.J., Zhang, Y.Z., Vykhodtseva, N., McDannold, N., 2012. Ultrasound-mediated blood-brain/blood-tumor barrier disruption improves outcomes with trastuzumab in a breast cancer brain metastasis model. Journal of Controlled Release 163, 277-284.

Patel, T., Zhou, J.B., Piepmeier, J.M., Saltzman, W.M., 2012. Polymeric nanoparticles for drug delivery to the central nervous system. Advanced Drug Delivery Reviews 64, 701-705.

Peluffo, H., et al., 2015. BBB-targeting, protein-based nanomedicines for drug and nucleic acid delivery to the CNS. Biotechnology Advances 33, 277-287.

Posadas, I., Monteagudo, S., Cena, V., 2016. Nanoparticles for brain-specific drug and genetic material delivery, imaging and diagnosis. Nanomedicine 11, 833-849.

Rappaport, J., Garnacho, C., Muro, S., 2014. Clathrin-mediated endocytosis is impaired in type A-B Niemann-pick disease model cells and can be restored by ICAM-1-mediated enzyme replacement. Molecular Pharmaceutics 11, 2887-2895.

Rauck, B.M., Novosat, T.L., Oudega, M., Wang, Y.D., 2015. Biocompatibility of a coacervate-based controlled release system for protein delivery to the injured spinal cord. Acta Biomaterialia 11, 204-211. 
Rotman, M., et al., 2015. Enhanced glutathione PEGylated liposomal brain delivery of an anti-amyloid single domain antibody fragment in a mouse model for Alzheimer's disease. Journal of Controlled Release 203, 40-50.

Salvalaio, M., et al., 2016. Targeted polymeric nanoparticles for brain delivery of high molecular weight molecules in lysosomal storage disorders. PLoS One 11, e0156452.

Schwarze, S.R., Ho, A., Vocero-Akbani, A., Dowdy, S.F., 1999. In vivo protein transduction: Delivery of a biologically active protein into the mouse. Science 285, $1569-1572$.

Serna, N., et al., 2016. Rational engineering of single-chain polypeptides into protein-only, BBB-targeted nanoparticles. Nanomedicine-Nanotechnology Biology and Medicine $12,1241-1251$.

Singh, B., Kapil, R., 2011. In: Brain drug delivery: Problems and prospects. 63rd Indian pharmaceutical congress.

Smith, Q.R., Allen, D.D., 2003. In situ brain perfusion technique. Methods in Molecular Medicine 89.

Sohn, Y.B., et al., 2015. Safety and efficacy of enzyme replacement therapy with idursulfase beta in children aged younger than 6 years with Hunter syndrome. Molecular Genetics and Metabolism 114, 156-160.

Sorrentino, N.C., et al., 2013. A highly secreted sulphamidase engineered to cross the blood-brain barrier corrects brain lesions of mice with mucopolysaccharidoses type IIIA. EMBO Molecular Medicine 5, 675-690.

Spencer, B., et al., 2014. ESCRT-mediated uptake and degradation of brain-targeted alpha-synuclein single chain antibody attenuates neuronal degeneration in vivo. Molecular Therapy 22, 1753-1767.

Spencer, B., et al., 2014. A neuroprotective brain-penetrating endopeptidase fusion protein ameliorates Alzheimer disease pathology and restores neurogenesis. Journal of Biological Chemistry 289, 17917-17931.

Spencer, B. et al. A brain-targeted, modified neurosin (kallikrein-6) reduces alpha-synuclein accumulation in a mouse model of multiple system atrophy. Molecular Neurodegeneration 10 (2015), 48.

Steichen, S.D., Caldorera-Moore, M., Peppas, N.A., 2013. A review of current nanoparticle and targeting moieties for the delivery of cancer therapeutics. European Journal of Pharmaceutical Sciences 48, 416-427.

Teixido, M., Giralt, E., 2012. Present and future of peptides as blood-brain barrier shuttles. Journal of Peptide Science 18, S49-S50.

Tosi, G., Costantino, L., Ruozi, B., Forni, F., Vandelli, M.A., 2008. Polymeric nanoparticles for the drug delivery to the central nervous system. Expert Opinion on Drug Delivery $5,155-174$.

Tosi, G., et al., 2016. The "fate" of polymeric and lipid nanoparticles for brain delivery and targeting: Strategies and mechanism of blood-brain barrier crossing and trafficking into the central nervous system. Journal of Drug Delivery Science and Technology $32,66-76$.

Upadhyay, R.K., 2014. Drug delivery systems, CNS protection, and the blood brain barrier. BioMed Research International 2014, 869269.

Vuillemenot, B.R., et al., 2011. Intrathecal tripeptidyl-peptidase 1 reduces lysosomal storage in a canine model of late infantile neuronal ceroid lipofuscinosis. Molecular Genetics and Metabolism 104, 325-337. 
Vuillemenot, B.R., et al., 2015. Nonclinical evaluation of CNS-administered TPP1 enzyme replacement in canine CLN2 neuronal ceroid lipofuscinosis. Molecular Genetics and Metabolism 114, 281-293.

Vykhodtseva, N., McDannold, N., Hynynen, K., 2008. Progress and problems in the application of focused ultrasound for blood-brain barrier disruption. Ultrasonics 48 , 279-296.

Wang, F., et al., 2012. Targeted delivery of GDNF through the blood-brain barrier by MRI-guided focused ultrasound. PLoS One 7.

Watts, R.J., Dennis, M.S., 2013. Bispecific antibodies for delivery into the brain. Current Opinion in Chemical Biology 17, 393-399.

WHO, 2001. Mental disorders affect one in four people. In: http://www.who.int/whr/2001/ media_centre/press_release/en/.

Wilhelm, I., Krizbai, I.A., 2014. In vitro models of the blood-brain barrier for the study of drug delivery to the brain. Molecular Pharmaceutics 11, 1949-1963.

Wohlfart, S., Gelperina, S., Kreuter, J., 2012. Transport of drugs across the blood-brain barrier by nanoparticles. Journal of Controlled Release 161, 264-273.

Wolak, D.J., Thorne, R.G., 2013. Diffusion of macromolecules in the brain: Implications for drug delivery. Molecular Pharmaceutics 10, 1492-1504.

Wong, H.L., Wu, X.Y., Bendayan, R., 2012. Nanotechnological advances for the delivery of CNS therapeutics. Advanced Drug Delivery Reviews 64, 686-700.

Wu, X.Q., Zheng, T.T., Zhang, B.R., 2016. Exosomes in Parkinson's disease. Neuroscience Bulletin 33, 331-338.

$\mathrm{Xu}$, J.F., et al., 2016. A novel dual-targeted ultrasound contrast agent provides improvement of gene delivery efficiency in vitro. Tumor Biology 37, 8609-8619.

Yi, X., Kabanov, A.V., 2013. Brain delivery of proteins via their fatty acid and block copolymer modifications. Journal of Drug Targeting 21, 940-955.

Yi, X., Manickam, D.S., Brynskikh, A., Kabanov, A.V., 2014. Agile delivery of protein therapeutics to CNS. Journal of Controlled Release 190, 637-663.

Young, S.W.S., Stenzelb, M., Yang, J.-L., 2016. Nanoparticle-siRNA: A potential cancer therapy?. Critical Reviews in Oncology/Hematology 98, 159-169.

Yu, K., Liu, C.C., Kim, B.G., Lee, D.Y., 2015. Synthetic fusion protein design and applications. Biotechnology Advances 33, 155-164.

Yun, X., et al., 2013. Nanoparticles for targeted delivery of antioxidant enzymes to the brain after cerebral ischemia and reperfusion injury. Journal of Cerebral Blood Flow and Metabolism 33, 583-592.

Zhao, Y., et al., 2011. Active targeted macrophage-mediated delivery of catalase to affected brain regions in models of Parkinson's disease. Journal of Nanoscience and Nanotechnology 4, 21.

Zhao, Y.L., et al., 2014. GDNF-transfected macrophages produce potent neuroprotective effects in Parkinson's disease mouse model. PLoS One 9, e106867.

Zhao, Y.Z., et al., 2016. Intranasal delivery of bFGF with nanoliposomes enhances in vivo neuroprotection and neural injury recovery in a rodent stroke model. Journal of Controlled Release 224, 165-175.

Zuchero, Y.J.Y., et al., 2016. Discovery of novel blood-brain barrier targets to enhance brain uptake of therapeutic antibodies. Neuron 89, 70-82. 